\title{
Bio-Texturisation of Soy Protein Isolate
}

\author{
Dalia, H. Eshra \\ Food Science and Technology Dept., Fac. of Agric., \\ Alexandria University, El-Shatby, 21545, Alexandria, Egypt.
}

\begin{abstract}
The possibility of using microbial transglutaminase (MTGase, 2.3.2.13) on bio-texturising of soy protein isolate is the main object of this study. Covalent cross-linking of proteins by MTGase is easy and simple for application, safe and well controlled process than commercial methods used for protein texturisation. Two commercial preparations of MTGase were used for restructuring soy protein isolate (SPI). The investigation of the product (gel) formed was evaluated using textural profile analysis (TPA). The results indicated that using of MTGase for texturising of SPI enhance greatly most of TPA parameters. The most affected parameters were hardness, cohesiveness and gumminess. Bio- texturising of proteins is a promising tool for restructuring and modifying the structure net work of protein molecules. The cross-linking reactions promoted by the action of MTGase allowing for the development and widespread use of new and improved functional properties in food industry.
\end{abstract}

Keywords: Bio-texturisation, microbial transglutaminase, plant proteins, soy protein isolate, textural parameters.

\section{INTRODUCTION}

Proteins are one of the main food components; hence their modifications via chemical, physical or enzymatic methods are alternative available tools for improvement and/ or development of new functional properties of protein-based foods (Gaspar \& Góes-Favoni, 2015).

Plant proteins occupy an important place in human nutrition, especially in the diets of low-income earners of developing countries. Furthermore, animal proteins are scarce in many countries, and vegetable proteins have a lower price than muscle proteins. Besides, it is well known that meat contains cholesterol and a higher proportion of saturated fatty acids than polyunsaturated fatty acids, which exert suppressive effects on pathogenesis of many diseases (Asgar et al., 2010).

The functional properties of proteins are the physiochemical properties that affect their behavior in food systems, contributing to its quality and sensory or acceptability i.e., texture, appearance and flavour (Gaspar \& Góes-Favoni, 2015).

Enzymatic texturising of protein or bio-texturising of protein is a promising tool for modification of protein molecules. The commercial enzyme, (MTGase), demonstrated its potential application in vegetable products such as soy which is little exploited in the market (Góes-Favoni \& Bueno, 2014). MTGase still rarely been used in texturisation of plant proteins. However, there is an increasing demand for vegetarian foods in many branches of the food industry (Dube et al., 2007, Piestrasik et al., 2007, Chang et al., 2011).The enzyme MTGase catalyses acyl transfer reaction forming inter-and intramolecular cross-links between amino acid residues of glutamine and lysine of protein molecules. The MTGase has several characteristics which covering many applications in food technology. The enzyme does not alter the $\mathrm{pH}$, colour or flavour of food and it is active in a wide range of $\mathrm{pH}$ ranging from 4.0 to 9.0 (Ando et al., 1989, Cui et al., 2007).

With respect to substrate specificity, the enzyme has a broad specificity, so most food proteins could be cross-linked by MTGase (Nonaka et al., 1997). Besides, the enzyme is capable of incorporating amino acids or peptides covalently into proteins, which improve nutritive value of food proteins (Yokoyama \& Kikuchi, 2004).A practical application of this enzyme is the formation of heat-stable and irreversible gels, which could be obtained in different substrates even at relatively low protein concentrations (Góes-Favoni \& Bueno, 2014). Covalent conjugation of two or more proteins of different origins may also be triggered by MTGase, generating a new protein with properties 
different from those of original proteins (Gerrard, 2002). Several studies have reported that MTGase does not pose health risks and has no microbial antigenic potential (Seguro et al., 1996, Kuraishi et al., 2001).

Textural profile analysis (TPA) covered a wide range of food textural properties, which are usually divided into two main groups; primary and secondary. The primary parameters are those which could be measured directly from the TPA curve including; hardness (firmness), fructurability (brittleness), cohesiveness (stickiness), adhesiveness and springiness (elasticity). The secondary parameters, gumminess and chewiness are those that could be adequately calculated from two or more of the primary parameters. Generally, TPA could be used correctly for solid and semisolid foods. All of the TPA parameters must not present for all tested samples. Gumminess is only applicable to semisolids and is mutually exclusive with chewiness. Also, the parameters of viscosity and brittleness are found to be mutually exclusive. Only solids can have the characteristic of brittleness, whereas viscosity is limited, in the classification of liquid and semisolid products. The TPA test is simple and the textual parameters deduced intuitively understandable, it has become very popular. The result can be very misleading if the test is not conducted with the proper operational settings. Comparisons between TPA results are only likely to be valid if identical test protocols including the test geometry, speed and percentage of compression, are all kept constant (Bourne, 1978, Rosenthal, 2010, Trinh \& Glasgow, 2012).

The present study focuses on the bio-texturising of soy protein isolate using MTGase and its opportunities to modify and improve many of the main functional properties of proteins. The effect of two commercially MTGase preparation on cross-linking of soy protein isolate was studied. The main textural properties of the gel formed were evaluated using texture profile test.

\section{MATERIALS AND METHODS}

\section{Materials}

Soy protein isolate, SPI, (SSPI-90D1W, Linyi Shansong Biological Products Co., Ltd. China) was used in the present study. The SPI was stored in a closed container at $4^{\circ} \mathrm{C}$ until used. Two commercial preparations of microbial transglutaminase obtained from Ajinomoto Foods Europe, S.A.S. France and Mühlenchemie GmbH \& Co.KG, Germany. They were designated as $\mathrm{E}_{1}$ and $\mathrm{E}_{2}$, respectively. All the chemicals used were analytical grade.

\section{Methods}

\section{MTGase activity}

The enzyme activity was determined using the colorimetric hydroxamte procedure with N-Carbobenzoxy-L-glycine. A calibration curve was prepared using $\gamma$-glutamic acid $\gamma$-monohydroxamte (Macedo et al., 2007).

\section{Preparation of gel samples}

Soy protein isolate $(30 \mathrm{~g})$ were mixed with $45 \mathrm{ml}$ of distilled water containing $0.6 \mathrm{~g}$ MTGase, which representing $2 \% \mathrm{w} / \mathrm{w}$ of the amount of SPI used (Min \& Green, 2008). After mixing, the resulted paste was placed into Petri dishes and incubated at $37^{\circ} \mathrm{C}$ for $30,60,90$ and $120 \mathrm{~min}$. These treatments were assigned as $\mathrm{T} 2, \mathrm{~T} 3, \mathrm{~T} 4$ and $\mathrm{T} 5$ for each enzyme preparation. For enzyme free samples (control, T1), the same process was followed, but no enzyme was added (Taylor \& Walsh, 2001, Chang et al., 2011).

\section{Texture Profile Analysis (TPA)}

TPA of the gel formed was performed on the texture analyzer (TexturePro CTV1.2 Build 9, Brookfield Engineering Labs. Inc. England).At zero time and at the end of each incubation period, a piece $(3 \times 3 \mathrm{~cm})$ of the gel formed (height $1.5 \mathrm{~cm}$ ) was removed from the Petri dishes and placed on the platform (TA-RT-KI) with $10 \mathrm{Kg}$ load cell, trigger load $0.07 \mathrm{~N}$ and test speed $1.5 \mathrm{~mm} / \mathrm{s}$ using cylindrical plunger (TA 10). The samples were compressed to $50 \%$ of its original height at crosshead in two bites (Yuan \& Chang, 2007). The tested TPA parameters were; hardness, cohesiveness, springiness and gumminess. The measurements performed on three replicates.

\section{Statistical procedures}

F-test and analysis of variance of treatments difference was performed according to Steel \&Torrie (1980). Statistical analysis was done by, ANOVA, F-test, and least significant difference (LSD) procedures available within the SAS software package, version 9.13 2007. The following model was used to analyze data obtained in factorial experiment. 


$$
\mathrm{Yij}=\mu+\alpha \mathrm{i}+\mathrm{Bj}+\alpha \mathrm{Bij}+\mathrm{e} \mathrm{ij}
$$

Where; Yij = effect of enzymes with different incubation time; $\mu=$ overall mean; $\alpha \mathrm{i}=$ the effect of enzyme, $\mathrm{B}=$ the effect of time, $\alpha \mathrm{B}=$ interaction effect and e $\mathrm{ij}=$ random error assumed to be independently and randomly distributed.

\section{RESULTS AND DISCUSSION}

\section{Overall view}

The measured activity of the two enzymes used, $E_{1}$ and $E_{2}$, were $7.5 \pm 0.2 \mathrm{U} / \mathrm{g}$ of each enzyme preparation. So, an equal amount of enzymes were used. An identical protocol including; test geometry, compression speed, percentage of compression and other operating conditions are all kept constant for all tested samples so the results are likely to be valid (Rosenthal, 2010).The samples used in the present study were treated as semisolid materials; therefore gumminess rather than chewiness are presented in the results (Anonymous, 2012, Trinh \& Glasgow, 2012). A graphic of the two-bite, force distance texture profile analysis curves of the two MTGase used on bio- texturizing of soy protein isolate is presented in Fig. (1). For reason of space, the data at zero time and after $90 \mathrm{~min}$ of incubation are only presented. The main features of these TPA curves are summarized in the following points: (1) the curves show a steep initial slope which indicates that the samples tested have high hardness, (2) the smooth curves, sharp peaks and absence of shoulders suggests no fracturability and/ or no point of rupture or gross mechanical failure of the gel formed, (3) for adhesiveness, a low adhesiveness value was observed only in the control sample, while no noticeable values of adhesiveness were observed for all samples containing enzymes. This indicated that cross-linking of proteins by MTGase leads to overcome the low cohesiveness of the enzyme free samples (Piestrasik et al., 2007, Asgar et al., 2010, Rosenthal, 2010, Anonymous, 2012, Trinh \& Glasgow, 2012, Nishinari et al., 2013, Banjare et al., 2015).

The statistical analysis of the data obtained is presented in Table (1). These data revealed that there were significant differences within all the TPA parameters tested. The main observations are: (1) the effect of $E_{1}$ was generally higher than $E_{2}$, Table (1-A), (2) for time of incubation, Table (1B) showed an increasing of all TPA tested parameters by increasing the time of incubation for both enzymes, the highest increase was noticed through the first 30 min of incubation for both enzymes, (3) the interaction between the enzyme and the time of incubation, Table (1-C), indicated that addition of MTGase significantly increased all the tested TPA parameters of the gel formed.

\section{Interpretation of the TPA parameters}

Hardness refers to the force required to cause a given deformation. It represents the highest point

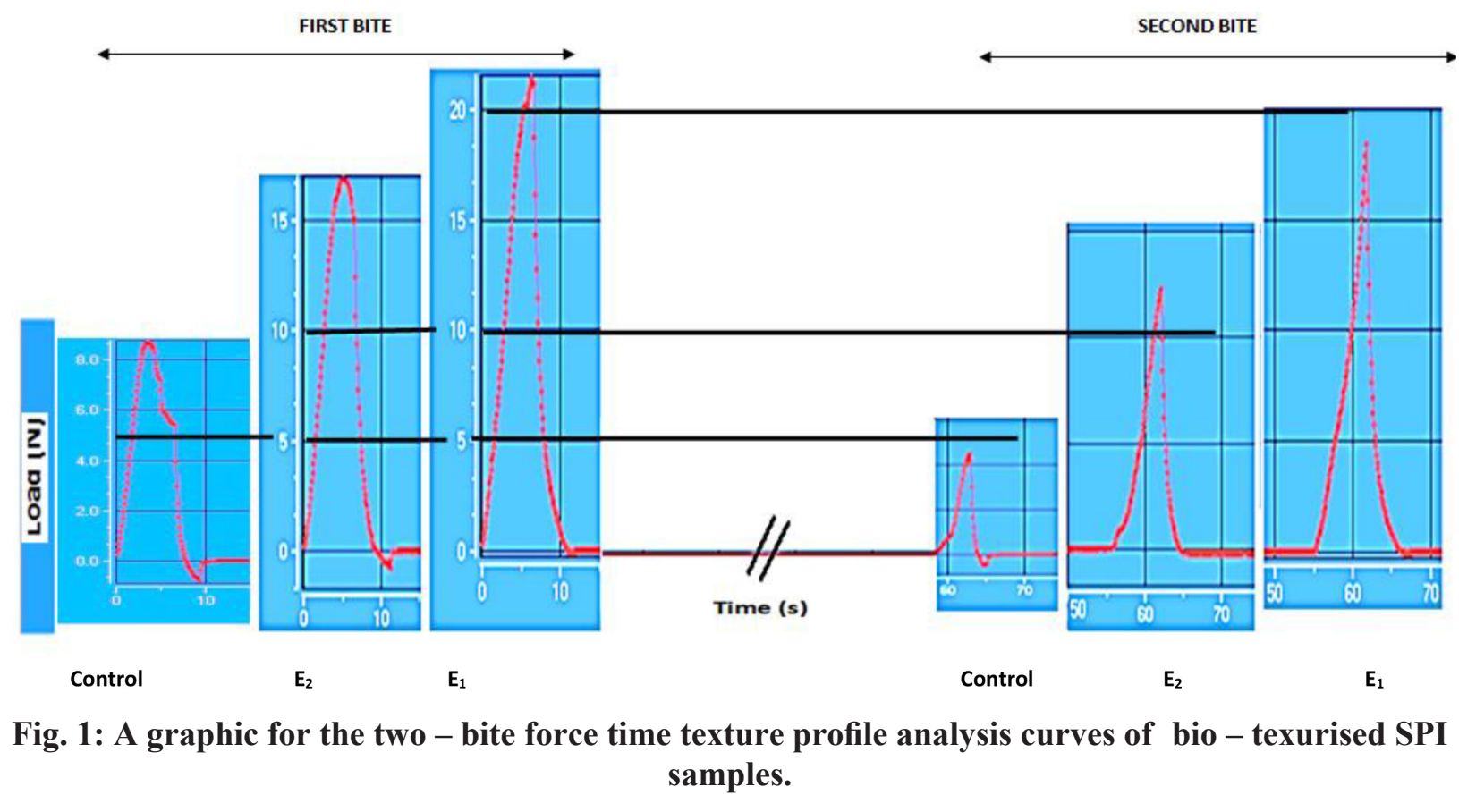

(The data shown is that at zero time ( control) and after 90 min of incubation for each enzyme $E_{1}$ and $E_{2}$ ). 
Table 1. Means of the texture profile parameters as influenced by enzymes, time of incubation and their interaction in soy protein isolate gel treatments.

\begin{tabular}{|c|c|c|c|c|}
\hline Factor & Hardness (N) & Cohesiveness & Springiness (mm) & Gumminess (N) \\
\hline & \multicolumn{4}{|c|}{ A. Enzyme } \\
\hline E1 & $16.46^{\mathrm{a}}$ & $0.4427^{\mathrm{a}}$ & $8.82 \mathrm{a}$ & $7.68^{\mathrm{a}}$ \\
\hline \multirow[t]{2}{*}{ E2 } & $14.49^{\mathrm{b}}$ & $0.3780^{\mathrm{b}}$ & $8.31^{\mathrm{a}}$ & $5.66^{\mathrm{b}}$ \\
\hline & \multicolumn{4}{|c|}{ B. Time of incubation (min) } \\
\hline $\mathrm{T} 1(0)$ & $8.69^{\mathrm{e}}$ & $0.208^{\mathrm{e}}$ & $5.400^{\mathrm{b}}$ & $1.84^{\mathrm{e}}$ \\
\hline $\mathrm{T} 2(30)$ & $13.55^{\mathrm{d}}$ & $0.350^{\mathrm{d}}$ & 9.290 a & $5.08^{\mathrm{d}}$ \\
\hline $\mathrm{T} 3(60)$ & $16.10^{c}$ & $0.435^{\mathrm{c}}$ & 9.015 a & $6.62^{c}$ \\
\hline $\mathrm{T} 4(90)$ & $19.14 \mathrm{~b}$ & $0.475^{b}$ & $9.478^{\text {a }}$ & $10.10^{\mathrm{a}}$ \\
\hline \multirow[t]{2}{*}{$\mathrm{T} 5(120)$} & $20.42^{\text {a }}$ & $0.515^{\mathrm{a}}$ & $9.645^{\text {a }}$ & $9.78^{b}$ \\
\hline & \multicolumn{4}{|c|}{ C. Enzyme * Time of incubation } \\
\hline $\mathrm{E} 1 * \mathrm{~T} 1$ & $8.69^{\mathrm{i}}$ & $0.206^{\mathrm{h}}$ & $7.07^{\mathrm{e}}$ & $1.84^{\mathrm{i}}$ \\
\hline $\mathrm{E} 1 * \mathrm{~T} 2$ & $14.66 \mathrm{~g}$ & $0.360 \mathrm{~g}$ & $9.14^{c}$ & $5.25^{\mathrm{h}}$ \\
\hline $\mathrm{E} 1 * \mathrm{~T} 3$ & $16.45^{\mathrm{e}}$ & $0.460^{\mathrm{c}}$ & $8.56^{\mathrm{d}}$ & $7.58^{\mathrm{d}}$ \\
\hline $\mathrm{E} 1 * \mathrm{~T} 4$ & 21.40 a & $0.600^{\mathrm{a}}$ & $9.79^{\mathrm{a}}$ & $12.89^{a}$ \\
\hline $\mathrm{E} 1 * \mathrm{~T} 5$ & $21.11 \mathrm{~b}$ & $0.510^{\mathrm{b}}$ & $9.54^{\mathrm{ab}}$ & $10.85^{b}$ \\
\hline $\mathrm{E} 2 * \mathrm{~T} 1$ & $8.69^{\mathrm{i}}$ & $0.210^{\mathrm{h}}$ & $7.07^{\mathrm{e}}$ & $1.84^{\mathrm{i}}$ \\
\hline $\mathrm{E} 2 * \mathrm{~T} 2$ & $12.44^{\mathrm{h}}$ & $0.400^{\mathrm{f}}$ & $9.44^{\mathrm{abc}}$ & $4.91 \mathrm{~g}$ \\
\hline $\mathrm{E} 2 * \mathrm{~T} 3$ & $15.75^{\mathrm{f}}$ & $0.410^{\mathrm{ef}}$ & $9.47 \mathrm{abc}$ & $5.66^{\mathrm{f}}$ \\
\hline $\mathrm{E} 2 * \mathrm{~T} 4$ & $16.87 \mathrm{~d}$ & $0.430^{\mathrm{de}}$ & $9.16^{\mathrm{bc}}$ & $7.18^{\mathrm{e}}$ \\
\hline $\mathrm{E} 2 * \mathrm{~T} 5$ & $19.72^{c}$ & $0.440^{\mathrm{cd}}$ & $9.75^{\mathrm{a}}$ & $8.71^{\mathrm{c}}$ \\
\hline LSD0.05 & .034 & 0.0244 & .311 & .017 \\
\hline
\end{tabular}

Means followed by the same letter(s) are not significant, but different

Letters are significant at 0.05 level of probability according to LSD method.

of the peak in the first compression cycle (Bourne, 1978). Hardness is the most representative parameters of TPA. It is the direct effect of action of MTGase on cross-linking of proteins (Gutt el al., 2014). Fig. (1) showed that the second peak is smaller than the first indicating some weaking of the internal structure of the gel formed. This effect is consistent with TPA as technique (Rosenthal, 2010). The data present in Table (1-C) and Fig. (2-A) showed that the two MTGases have a noticeable effect on the hardness of the gel formed with priority of $E_{1}$ than $\mathrm{E}_{2}$. The hardness was increased by increasing the incubation time to $90 \mathrm{~min}$ for $\mathrm{E}_{1}$ and extended to $120 \mathrm{~min}$ for $\mathrm{E}_{2}$. The highest value of hardness $(21.40 \mathrm{~N})$ was that of $\mathrm{E}_{1}$ after 90 min incubation which is about 2.5 times higher than that of the control. These results indicated that the cross-linking of proteins by MTGase strength the network structure of protein molecules and hence increase the gel hardness. These results are in agreement with that reported by Kuraishi et al. (2001).
Cohesiveness is a direct indication to how the test material adheres to itself, so its structural integrity opposes successfully compressive or tensile stress, it is affected by the chemical structure of the tested material (Anonymous, 2012). As shown in Table (1-C) and Fig. (2-B), the cohesiveness rose up from 0.206 to 0.600 for $E_{1}$, while it increased from 0.210 to 0.430 for $E_{2}$ for both the control samples and after 90 min incubation, respectively. Gaspar \& Góes-Favoni (2015) stated that the use of MTGase improved the textural properties including hardness and cohesiveness resulting in strong gels with a compact and ordered structural conformation.

Springiness is an indication of how much a deformed sample returns to its original size and shape. The less a product is destroyed, the more springiness it will be observed (Trinh \& Glasgow, 2012). For the two MTGase tested, springiness was moderately increased through the first $30 \mathrm{~min}$ of 
(A)

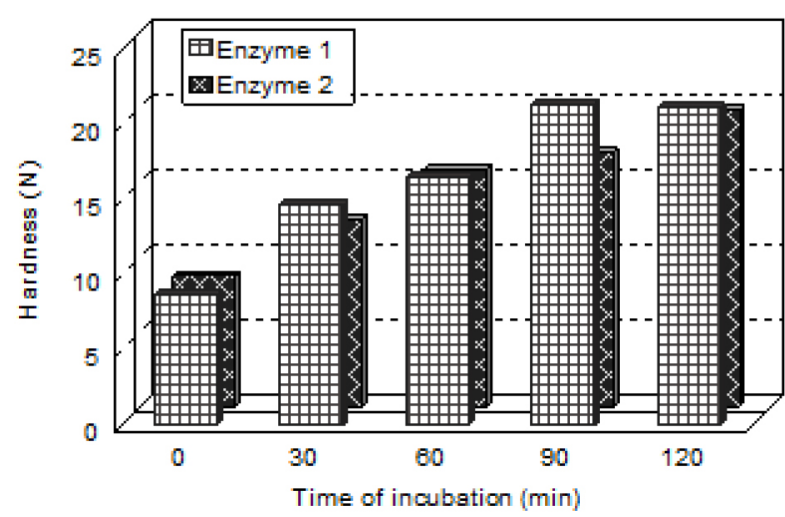

(c)

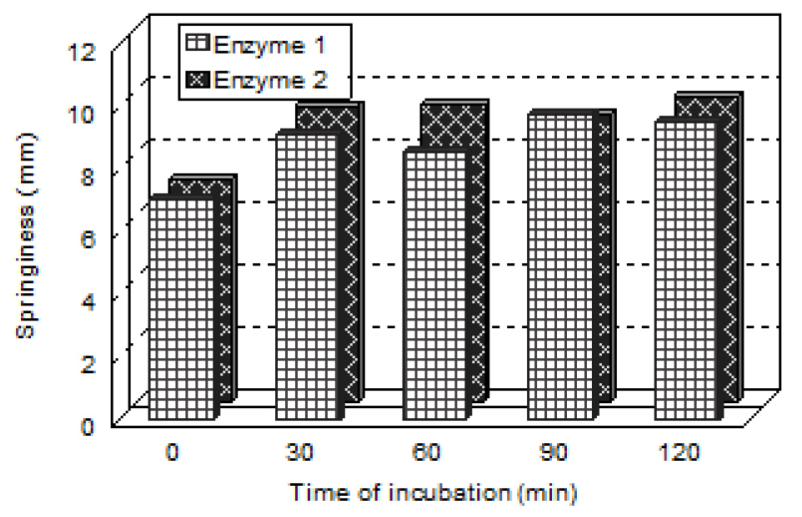

(B)

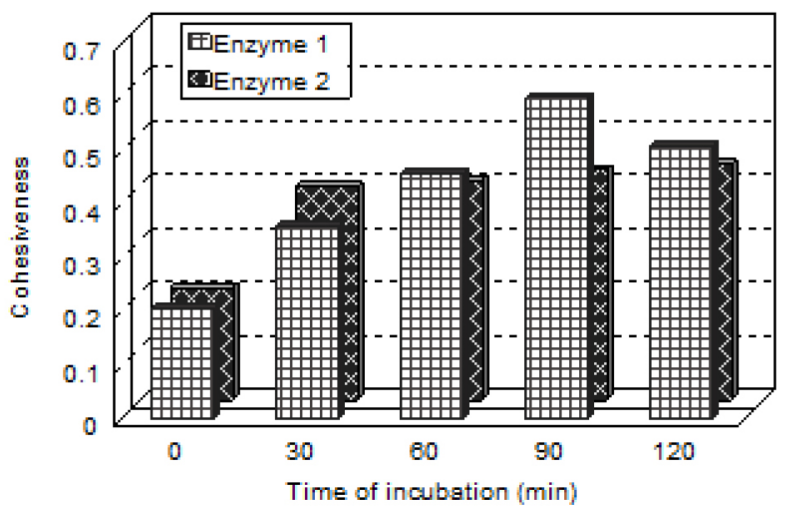

(D)

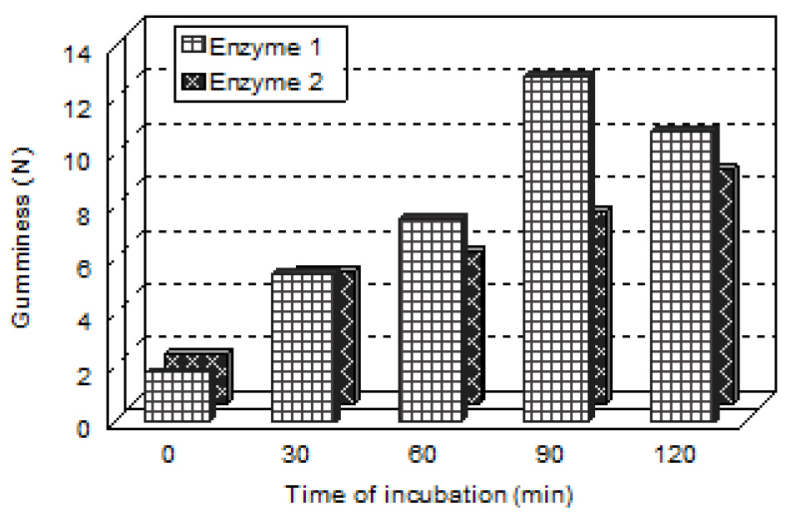

Fig. 2: Effect of incubation time on textural parameters of bio- texturised SPI treatments

incubation but less pronounced through the rest of incubation period (Table 1-C and Fig. 2-C). The springiness values of the control, after 30 and 120 min of incubation were $7.07,9.14$ and $9.54 \mathrm{~mm}$ for $E_{1}$ and $7.07,9.44$ and $9.75 \mathrm{~mm}$ for $E_{2}$, respectively.

Gumminess is one of the secondary parameters of TPA. It mainly refers to the semisolid material. Generally the results, Table (1-C) and Figure (2-D), indicated that the gel produced by $\mathrm{E}_{1}$ was gummier than that of $\mathrm{E}_{2}$. The maximum gumminess $(12.89 \mathrm{~N})$ was obtained after $90 \mathrm{~min}$ of incubation for $\mathrm{E}_{1}$, and then decreased to $10.85 \mathrm{~N}$ after $120 \mathrm{~min}$ of incubation.

\section{CONCLUSION}

Bio- texturising of proteins is a promising tool for restructuring and modifying the structure network of protein molecules. It is very simple process compared with the commercial methods used for production of structured protein. The process doesn't alter the $\mathrm{pH}$, colour or flavour of food. It will stop spontaneously when no more substrates, glutamine or lysine, available. The cross -linking reac- tions promoted by the action of MTGase allowing for the development and wide spread use of new and improved functional properties by the food industry.

\section{REFERENCES}

Ando, H., Adachi, M., Umeda, K., Matsuura, A., Nonaka, M., Uchio, R.,Tanaka, H.\& Motoki, M. 1989.Purification and characteristics of a novel transglutaminase derived from microorganisms. Agricultural and Biological Chemistry, 53: 2613-2617.

Anonymous. 2012. An overview of texture profile analysis (TPA). Texturetechnologies. Com/ resource/texture-profile-analysis.

Asgar, M.A., Fazilah, A., Huda, N., Bhat, R.\& Karim, A.A.2010. Nonmeat protein alternative as meat extenders and meat analogs. Comprehensive Reviews in Food Science and Food Safety, 9:513-529.

Banjare, K., Kumar, M., Goel, B.K.\&Uprit, S. 2015. Studies on chemical, texture and sensory characteristics of market and laboratory peda samples manufactured in Raipur city of 
Chhattisgarh. Oriental Journal of Chemistry, 31:231-238.

Bourne, M.C. 1978. Texture profile analysis. Food Technology, 32:62-66.

Chang, Y.H.O., Shiau, S.Y., Chen, F.U.B. \& Lin, F.R.U. 2011. Effect of microbial transglutaminase on the rheological and textural characteristics of black soybean packed tofu coagulating with Agar. LWT-Food Science and Technology, 44: 1107- 1112.

Cui, L., Du, G., Zhang, D., Liu, H.\& Chen, J. 2007. Purification and characterization of transglutaminase from a newly isolated Streptomyces hygroscopicus. Food Chemistry, 105: 612618.

Dube, M., Schäfer, C., Neidhart, S. \& Carle, R. 2007. Texturisation and modification of vegetable proteins for food applications using microbial transglutaminase. European Food Research and Technology, 225: 287- 299.

Gaspar, A.L.C. \& Góes-Favoni, S.P. 2015. Action of microbial transglutaminase (MTGase) in modification of food proteins: A review. Food Chemistry, 171:315-322.

Gerrard, J.A. 2002. Protein-protein cross linking in food: methods, consequences, applications. Trends in Food Science \& Technology, 13: 391-399.

Gutt, G.H.,Paduret, S., Amariei, S.\& Chelaru, M. 2014. Chopped meat freshness assessment by texture profile analysis. Lucrări - ŞtiinţificoSeria Zootehnie, 61: 87-91.

Góes-Favoni, S.P. \& Bueno, F.R. 2014. Microbial transglutaminase : general characteristics and performance in food processing technology . Food Biotechnology, 28:1-24.

Kuraishi, C., Yamazaki, K. \& Susa, Y. 2001. Transglutaminase: its utilization in the food industry. Food Reviews International, 17: 221-246.

Macedo, J.A., Sette, L.D. \&Sato, H.H. 2007. Optimization of medium composition for

transglutaminase production by a Brazilian soil Streptomyces. sp. Electronic Journal of

Biotechnology, 10: 618-626.

Min, B. \& Green, B.W.2008. Use of microbial transglutaminase and nonmeat protein to improve functional properties of low $\mathrm{NaCl}$, phosphate - free patties made from channel catfish (Ictalurus punctatus) belly flap meat. Journal of Food Science, 73:218-226.

Nishinari, K., Kohyama, K., Kumagi, H., Funami, T. \& Bourne, M.C. 2013.Parameters of texture profile analysis. Food Science and Technology Research, 19:519-521.

Nonaka, M., Matsuura, Y., Nakano, K.\& Motoki, M. 1997.Improvement of the $\mathrm{pH}$-solubility profile of sodium caseinate by using $\mathrm{Ca}^{2+}$ independent microbial transglutaminase with gelatin. Food Hydrocolloids, 11: 347- 349.

Piestrasik, Z., Jarmoluk, A.\& Shand, P.J. 2007.Effect of non-meat proteins on hydration and textural properties of pork meat gels enhanced with microbial transglutaminase. LWT-Food Science and Technology, 40:915-920.

Rosenthal, A.J. 2010.Texture profile analysis- how important are the parameters? Journal of Texture Studies, 41:672-684.

SAS Institute, Inc. 2007. Sastechnical Report AS / STAT Software: Change and Enhancements, User's Guide, Volume 2, version 9.1.3., $4^{\text {th }}$ ed, Cary, NC: SAS Institute, Inc.

Seguro, K., Kumazawa, Y., Kuraishi, C. Sakamoto, H. \& Motoki, M. 1996. The epsilon- (gammaglutamyl) lysine moiety in crosslinked casein is an available source of lysine for rats. Journal of Nutrition, 126: 2557-2562.

Steel, R.G. \& Torrie. 1980. Principles and procedures of statics $2^{\text {ed }}$. MC Graw Hill, New York, U.S.A.

Taylor, B.J. \&Walsh, M.K. 2001. Development and sensory analysis of a textured whey protein meatless patty. Journal of Food Science, 67:1555-1557.

Trinh, K.T. \& Glasgow, S. 2012.On the texture profile analysis test. Texturetechnologies. http:// www. conference. net. au / chemeca.

Yokoyama, K. \& Kikuchi, N.N.Y. 2004. Properties and applications of microbial transglutaminase. Applied Microbial Biotechnology, 64: 447- 454.

Yuan, S.\& Chang, S.K.C. 2007 . Texture profile of tofu as affected by Instron parameters and sample preparation, and correlation of Instron hardness and springiness with sensory scores. Journal of Food Science, 72:136-145. 


\title{
التشكيل البنائي الحيوي لمعزول بروتين الصويا
}

\author{
داليا حسن عشرة \\ قسه علوم و تقنية الأغذية - كلية الزراعة - الشاطبي-

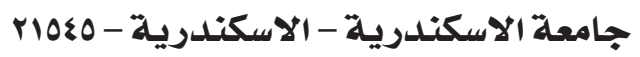

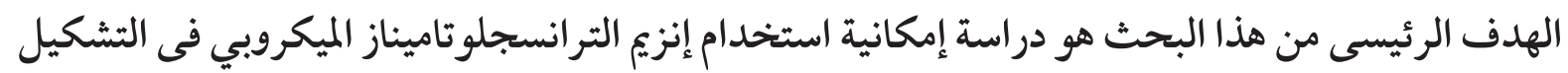

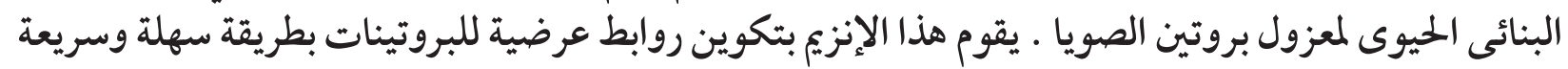

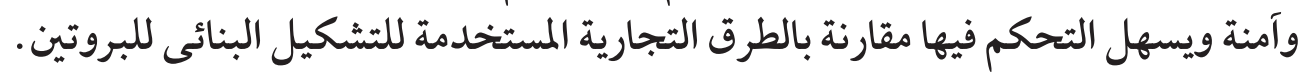

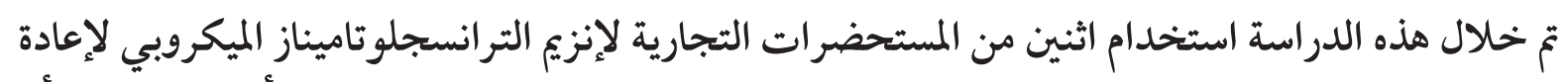

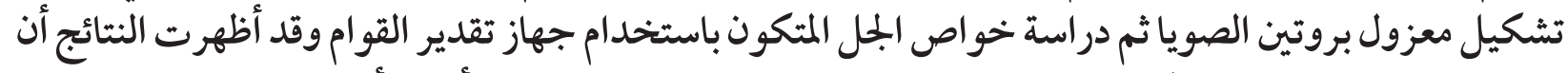

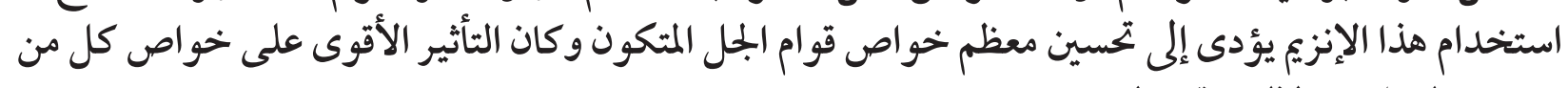
خواص الصلابة، الالتصاق والمضغ.

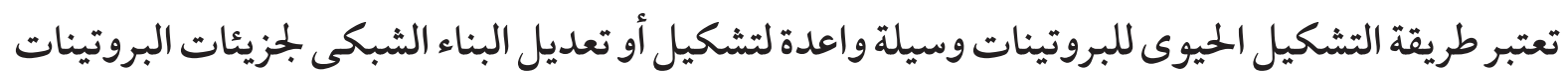

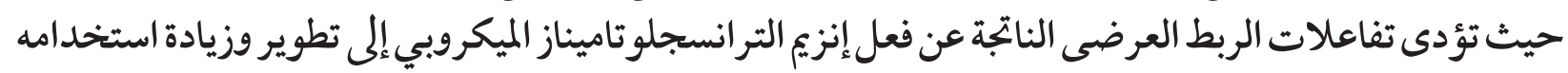
فى تحديث و تحسين الخو اص الوظيفية فى مجال التصنيع الغذائى. 
